\title{
Students' Perceptions on Studying Accounting Information System Course
}

\author{
Dr Helen Wong ${ }^{1} \&$ Dr Raymond Wong ${ }^{2}$ \\ ${ }^{1}$ Associate Head, Division of Business, Hong Kong Community College, The Hong Kong Polytechnic University, \\ Hong Kong \\ ${ }^{2}$ Senior Lecturer, School of Accountancy, The Chinese University of Hong Kong, Hong Kong \\ Correspondence: Dr Helen Wong, Associate Head, Division of Business, Hong Kong Community College, The \\ Hong Kong Polytechnic University, Hong Kong.
}

\author{
Received: January 26, 2017 \\ Accepted: February 14, 2017 \\ Online Published: February 24, 2017 \\ doi:10.5430/ijba.v8n2p1 \\ URL: http://dx.doi.org/10.5430/ijba.v8n2p1
}

\begin{abstract}
Information technology improves our lives and changes the business world. Business transactions and activities can now be handled by the computer system efficiently and effectively, and make the financial information quickly available for decision makers. Learning accounting information system becomes essential in nowadays study. Not only academic study at schools, professional bodies also require members to have knowledge in accounting information system. To understand the perceptions of students on the course of accounting information system, this study investigate their perceptions on ease of use, usefulness and acceptance. It provides insights to academics on planning the course of accounting information system for the students.
\end{abstract}

Keywords: accounting information system, ease of use, perceived usefulness, users acceptance, students

\section{Introduction}

With the rapid development of technology, the business world has undergone big changes in the recent few decades. In the past, all business transactions have to be manually recorded in order to produce financial statements for stakeholders' review. With the use of technology, companies can make use of accounting information system to record and process business activities and generate reports for decision makers and different stakeholders. Schools therefore incorporate accounting information system as a course for students, and this is especially essential for business students in their undergraduate studies which can equip them with necessary skills for pursuing their career in business.

Accounting Information System (AIS) is defined as "a set of interrelated activities, documents, and technologies designed to collect data, process it, and report to decision makers" in the accounting field (Hurt. 2013, p.4). AIS courses are important in that the American Institute of Certified Public Accountants (AICPA) has been stressing the critical roles of AIS in the service provided by accountants. Indeed, firms today expect college students with AIS knowledge and skills, leading to a growing demand from students to take AIS courses. Textbooks and other materials in the past, however, were inadequate to support the development of necessary AIS techniques and skills. AIS course curriculum, compared to those for other accounting topics, is also newly developed and still evolving. Many studies, therefore, have examined what should constitute the content of AIS courses. For example, Van Meer \& Adams (1996) identified three key areas, namely information technology, practical skills, and systems analysis, design and development that are considered important by academics and practitioners in New Zealand. In a similar vein, Groomer and Murthy (1996) examined factors that affect the content of AIS courses. Smith and Bain (1993) found that internal control and associated systems are the most important topics covered in AIS courses in the eyes of AIS faculty. More recently, Kearns (2014) confirmed that AIS knowledge is recognized by certified public accountants (CPAs). In Kearns's study (2014), surveyed CPAs considered spreadsheet tool is the most important whereas audit software and tool is the least important topic in AIS. These findings are somehow contrary to the expectation of academic educators. Therefore, how to design an appropriate AIS course curriculum that matches the needs of firms and students is still urging. Nevertheless, learning AIS in schools is important to students because it can equip them necessary skills for their future career. As studying AIS is vital, this research will study the students' perceptions on 
ease of use and usefulness of AIS functions and their acceptance of AIS course which can provide insights to educators on teaching AIS.

\section{Literature Review}

\subsection{Teaching Methods of AIS Courses}

Past researchers also investigated the methods of teaching AIS courses and their effectiveness. Drawing on the personal experience and a survey, $\mathrm{Wu}$ (1982) created a general teaching model for AIS courses. Hackbarth, Dow, and Janvrin (2010) found that the combination of computer classroom and traditional classroom is the most effective to promote students' performance in AIS courses. As online class becomes popular, Bressler, Manrique, and Bressler (2006) probed the factors that determine students' performance in online AIS courses. Other scholars also studied the use of specific tools, such as ERP software and service learning for AIS courses (e.g., Gujarathi, 2005; Rose, Rose, \& Norman, 2005). Mahoney and Welch (2002) introduced the use of personal computer movies for delivering the course content. In their argument, this high-tech tool is created easily by instructors and to be used by students. Charron and Raschke (2014) in a recent study found that using Skype and Jing to supplement with Netsuite accounting software could promote students' satisfaction.

\subsection{Students' Acceptance of AIS Courses}

While designing a practically relevant curriculum and employing effective teaching methods are essential for AIS education, it is no less important to motivate students to learn and accept the importance of AIS courses. Relatively only a few scholars and studies addressed this critical issue yet. In the study of Normand (2011) who investigated whether and how student perceptions on the importance of learning AIS change with the teaching method integrating textbook reading, in class projects, and reflection papers. The study found that the integrated approach increases students' perception on the importance of learning about AIS, while GPA, accounting-related work experience and gender have no impact on the perception. The study of Weli (2015) more explicitly identified the factors affecting student acceptance of AIS courses in India, and it found that students' attitude towards computer is positively related to the acceptance of AIS courses. These two studies provide clear normative implications that AIS course instructors should consider using the integrated teaching method and promoting students' attitude towards the use of computer. However, we still need more knowledge about how to motivate students to learn AIS in order to promote the effectiveness of student learning.

\subsection{Relationship between Perceived Ease of Use, Perceived Usefulness and Acceptance}

As learning AIS is important in nowadays' study, it is essential to understand whether there is a relationship among perceived ease of use, perceived usefulness and students' acceptance of AIS course. In a study of Davis (1989), six items are used to measure perceived ease of use of a computer system: learning to operate the system is easy for the user, easy to get the system to do what user wants, interaction with the system is clear and understandable, the system is flexible to interact with, it is easy to become skillful at using the system, and the user finds the system easy to use. To measure the usefulness of a computer system, six areas are used: work more quickly, improve job performance, increase productivity, enhance effectiveness, make job easier, and useful in job (Davis, 1989). Davis's study (1989) suggested that ease of use may be an antecedent of usefulness rather than a parallel direct determinant of usage of a system. His result also suggested that usefulness mediates the link between ease of use and usage of a system.

Van der Heijden (2004) suggested that perceived ease of use has significant impact on perceived usefulness and perceived enjoyment of the website. In the study of Igbaria et al. (1996) on managers and professionals about the use of microcomputer, the result suggested that perceived ease of use has significant direct and indirect impact over perceived usefulness and perceived enjoyment on system usage.

In some studies (e.g. Venkatesh, 2000; Szajna, 1996; Taylor \& Todd, 1995), the result suggested that perceived ease of use has indirect impact on behavior intention via perceived usefulness. Behavior intention can be measured in terms of word-of-mouth and / or intention to use. When users perceive the system is easy to use, users can finish the same amount of work in a shorter period of time and therefore perceive it to be useful. In the study of Igbaria et al. (1995) on employees about the use of computer system, the result suggested that perceived ease of use significantly influences behavior intention and perceived enjoyment.

Based on the above mentioned studies, this research aims to investigate whether the students' acceptance of AIS course is determined by the ease of use of the AIS functions and this relationship is mediated by the perceived usefulness of the AIS functions. Researchers in different fields have applied similar model in different technological contexts, including information and communication technology (Edmunds, Thorpe \& Conole, 2012), online-learning 
(Lee, 2008), electronic commerce (Pavlou, 2003), and e-mail (Gefen and Straub, 1997) etc. Three hypotheses for this study are:

H1: Perceived ease of use of AIS functions has a positive direct effect on the perceived usefulness of AIS functions.

H2: Perceived usefulness of AIS functions has a positive direct effect on students' acceptance of AIS course.

H3: The impact of perceived ease of use of AIS functions on students' acceptance of AIS course is mediated by the perceived usefulness of AIS functions.

\section{Research Method}

\subsection{Pilot Study}

This study is based on primary data. With reference to Sun \& Zhang (2006) and Davis (1989), questions are adapted to draft a survey form for a pilot study. To ensure respondents understand the questions and answer properly, the draft questionnaire was given to ten students for completion and comment. Based on their comments and suggestions, revisions were made and a final questionnaire was completed for data collection.

The final questionnaire consists of four parts. Part one asks about demographic information of respondents. Part two to Part four consist of four statements each asking students' perception on ease of use of AIS functions, usefulness of AIS functions, and acceptance of AIS course. A 7-point Likert scale ranging from "strongly disagree" to "strongly agree" is used to obtain their perceptions.

\subsection{Sample}

350 survey forms were distributed to students. 334 respondents returned the completed questionnaires. After removing the incomplete responses, the completed responses were 315 . Among the completed responses, $40 \%$ were pursuing a bachelor degree, $57 \%$ were associate degree students, and 3\% were higher diploma students. The respondents were from a variety of major areas $(33.02 \%$ in Accounting, 3.17\% in Accounting and Finance, $0.63 \%$ in Economics Studies, $8.89 \%$ in Integrated B.B.A., 1.59\% in International Business, $7.94 \%$ in Management, $16.51 \%$ in Marketing, $6.67 \%$ in Quantitative Finance, and $21.58 \%$ in Others). The average age of the students was about 19, and $98.73 \%$ of them were single.

\subsection{Type of Analysis}

Structural equation model (SEM) was being used to conduct the analysis. SEM is able to account for the measurement errors in the latent constructs. It also offers global tests of the entire model to assess the extent to which the entire model is consistent with the data (Kline, 1998). In this study, the two-step analysis (Anderson \& Gerbing, 1988) was performed to confirm the measurement model before testing the hypotheses and the global fitness of overall model.

\section{Research Analysis}

\subsection{Reliability and Validity of Measures}

To assess the validity of the measurement model, reliability and validity analysis for the three latent constructs were performed. Following Gerbing and Anderson (1988), the reliability and unidimensionality of the three constructs were assessed. The Cronbach's alpha for each construct is shown in Table 1. The Cronbach's alpha was above 0.94 for all constructs, providing strong evidence for the internal consistency of indicators under each latent construct. Following Germain, Droge \& Daugherty (1994), principle component analysis was run for each latent construct. It was found that only the first eigenvalue was greater than 1 for each construct, lending support for the unidimensionality of the scales.

As suggested by Bagozzi, Yi \& Phillips (1991), the discriminant validity of the three latent constructs was tested in this study. Confirmatory factor analysis for the three constructs without imposing any constraints was conducted first, and then the correlation between two of the three constructs was constrained to unity each time and conducted a chi-square difference test for the constrained and unconstrained models. The poor fit indexes in the constrained models (the chi-square differences were all significant at $p<0.01$ ) showed that the three latent constructs were not perfectly correlated to each other, providing evidence for discriminant validity for the three constructs.

The standardized loadings between indicators and latent constructs from the confirmatory factor analysis are shown in Table 1. All the indicators load significantly on their corresponding constructs at one percent level and the loadings were all above 0.8 , suggesting the convergent validity of the measures. The global fit indexes also indicated that the data were consistent with the measurement model $(\chi 2=154.89, \mathrm{df}=51$; CFI $=0.97$; RMSEA $=0.08$; SRMR 
$=0.03)$. Having considered all the result together, the measurement model was confirmed and could be used for the SEM to test the hypotheses. The correlations among all the variables are shown in Table 2.

Table 1. The descriptive statistics of indicators and latent constructs

\begin{tabular}{|c|c|c|c|c|c|}
\hline Latent constructs & Mean & S.D. & $\begin{array}{l}\text { Standardized } \\
\text { loading }\end{array}$ & T value & $\begin{array}{l}\text { Cronbach's } \\
\text { Alpha }\end{array}$ \\
\hline Perceived ease of use of AIS functions & & & & & 0.94 \\
\hline $\begin{array}{l}\text { E1. Learning to operate AIS functions is easy } \\
\text { for me. }\end{array}$ & 4.43 & 1.12 & 0.91 & 73.68 & \\
\hline $\begin{array}{l}\text { E2. I find it easy to get AIS functions to do } \\
\text { what I want it to do. }\end{array}$ & 4.43 & 1.08 & 0.91 & 73.90 & \\
\hline $\begin{array}{l}\text { E3. It is easy for me to become skillful at } \\
\text { using AIS functions. }\end{array}$ & 4.45 & 1.13 & 0.83 & 43.05 & \\
\hline E4. I find AIS functions easy to use. & 4.42 & 1.10 & 0.93 & 85.39 & \\
\hline Perceived usefulness of AIS functions & & & & & 0.95 \\
\hline $\begin{array}{l}\text { U1. Using AIS functions enhances my } \\
\text { effectiveness in work. }\end{array}$ & 4.86 & 1.10 & 0.90 & 73.35 & \\
\hline $\begin{array}{l}\text { U2. Using AIS functions enhances my } \\
\text { productivity. }\end{array}$ & 4.85 & 1.13 & 0.93 & 95.95 & \\
\hline U3. AIS functions are useful in my work. & 4.87 & 1.16 & 0.92 & 85.75 & \\
\hline $\begin{array}{l}\text { U4. Using AIS functions improves my } \\
\text { performance in work. }\end{array}$ & 4.83 & 1.11 & 0.91 & 77.31 & \\
\hline
\end{tabular}

\begin{tabular}{llllll}
\hline AIS course acceptance & & & & 0.94 \\
\hline A1. I intend to take AIS course in the future. & 4.27 & 1.42 & 0.93 & 91.05 \\
\hline $\begin{array}{l}\text { A2. I predict I would take AIS course in the } \\
\text { future. }\end{array}$ & 4.24 & 1.40 & 0.93 & 87.73 \\
\hline $\begin{array}{l}\text { A3. I would encourage my classmates to take } \\
\text { AIS course. }\end{array}$ & 4.19 & 1.37 & 0.85 & 46.40 \\
\hline $\begin{array}{l}\text { A4. I would say positive things about AIS } \\
\text { course to others. }\end{array}$ & 4.41 & 1.28 & 0.88 & 57.97 \\
\hline
\end{tabular}


Table 2. Descriptive statistics and correlations

\begin{tabular}{|c|c|c|c|c|c|c|c|c|c|c|c|c|c|c|c|c|c|c|c|}
\hline & Variables & Mean & S.D. & 1 & 2 & 3 & 4 & 5 & 6 & 7 & 8 & 9 & 10 & 11 & 12 & 13 & 14 & 15 & 16 \\
\hline 1. & $\begin{array}{l}\text { Perceived } \\
\text { ease of use of } \\
\text { AIS functions }\end{array}$ & 4.43 & 1.02 & 1.00 & & & & & & & & & & & & & & & \\
\hline 2. & $\begin{array}{l}\text { Perceived } \\
\text { usefulness of } \\
\text { AIS functions }\end{array}$ & 4.85 & 1.06 & $0.57^{* *}$ & 1.00 & & & & & & & & & & & & & & \\
\hline 3. & $\begin{array}{l}\text { AIS course } \\
\text { acceptance }\end{array}$ & 4.28 & 1.26 & $0.24^{* *}$ & $0.43^{* *}$ & 1.00 & & & & & & & & & & & & & \\
\hline 4. & Age & 19.23 & 0.90 & 0.06 & 0.05 & 0.06 & 1.00 & & & & & & & & & & & & \\
\hline 5. & $\begin{array}{l}\text { Male } \\
\text { (Dummy) }\end{array}$ & 0.41 & 0.49 & -0.02 & -0.06 & 0.01 & 0.03 & 1.00 & & & & & & & & & & & \\
\hline 6. & $\begin{array}{l}\text { Single } \\
\text { (Dummy) }\end{array}$ & 0.99 & 0.11 & 0.10 & 0.09 & 0.05 & -0.07 & -0.08 & 1.00 & & & & & & & & & & \\
\hline 7. & $\begin{array}{l}\text { Bachelor } \\
\text { degree } \\
\text { (dummy) }\end{array}$ & 0.40 & 0.49 & $0.14^{*}$ & $0.21^{* *}$ & $-0.13^{*}$ & $0.32^{* *}$ & 0.06 & -0.08 & 1.00 & & & & & & & & & \\
\hline 8. & $\begin{array}{l}\text { Associate } \\
\text { degree } \\
\text { (dummy) }\end{array}$ & 0.57 & 0.50 & -0.10 & $-0.15^{* *}$ & $0.16^{* *}$ & $-0.29 * *$ & -0.01 & 0.07 & $-0.93^{* *}$ & 1.00 & & & & & & & & \\
\hline 9. & $\begin{array}{l}\text { Accounting } \\
\text { (dummy) }\end{array}$ & 0.33 & 0.47 & 0.00 & 0.01 & $0.22^{* *}$ & $0.23^{* *}$ & -0.06 & 0.08 & $-0.13^{*}$ & $0.17^{* *}$ & 1.00 & & & & & & & \\
\hline 10. & $\begin{array}{l}\text { Accounting } \\
\text { and Finance } \\
\text { (dummy) }\end{array}$ & 0.03 & 0.18 & -0.01 & 0.04 & 0.05 & 0.01 & -0.00 & 0.02 & -0.04 & -0.06 & $-0.13^{*}$ & 1.00 & & & & & & \\
\hline 11. & $\begin{array}{l}\text { Economics } \\
\text { Studies } \\
\text { (dummy) }\end{array}$ & 0.01 & 0.08 & 0.03 & 0.00 & 0.09 & 0.02 & 0.10 & $-0.35 * *$ & 0.10 & -0.09 & -0.06 & -0.01 & 1.00 & & & & & \\
\hline 12. & $\begin{array}{l}\text { Integrated } \\
\text { B.B.A } \\
\text { (dummy) }\end{array}$ & 0.09 & 0.29 & 0.03 & 0.07 & $-0.13^{*}$ & 0.04 & -0.01 & 0.04 & $0.39 * *$ & $-0.36 * *$ & $-0.22^{* *}$ & -0.06 & -0.03 & 1.00 & & & & \\
\hline 13. & $\begin{array}{l}\text { International } \\
\text { Business } \\
\text { (dummy) }\end{array}$ & 0.02 & 0.13 & 0.01 & 0.09 & -0.00 & -0.03 & -0.00 & 0.01 & $0.16^{* *}$ & $-0.15^{*}$ & -0.09 & -0.02 & -0.01 & -0.04 & 1.00 & & & \\
\hline 14. & $\begin{array}{l}\text { Management } \\
\text { (dummy) }\end{array}$ & 0.08 & 0.27 & -0.02 & 0.04 & -0.04 & 0.04 & -0.05 & 0.03 & 0.05 & $-0.12^{*}$ & $-0.21^{* *}$ & -0.05 & -0.02 & -0.09 & -0.04 & 1.00 & & \\
\hline 15. & $\begin{array}{l}\text { Marketing } \\
\text { (dummy) }\end{array}$ & 0.17 & 0.37 & -0.04 & -0.02 & -0.11 & $-0.18^{* *}$ & $-0.14^{*}$ & -0.03 & -0.06 & 0.08 & $-0.31^{* *}$ & -0.08 & -0.04 & $-0.14^{*}$ & -0.06 & $-0.13^{*}$ & 1.00 & \\
\hline 16. & $\begin{array}{l}\text { Quantitative } \\
\text { Finance } \\
\text { (dummy) }\end{array}$ & 0.07 & 0.25 & 0.04 & 0.05 & -0.06 & $0.16^{* *}$ & $0.22^{* *}$ & $-0.20^{* *}$ & $0.33^{* *}$ & $-0.31^{* *}$ & $-0.19 * *$ & -0.05 & -0.02 & -0.08 & -0.03 & -0.08 & $-0.12^{*}$ & 1.00 \\
\hline
\end{tabular}

Note. $\mathrm{n}=315 .{ }^{*} \mathrm{p}<0.05 ;{ }^{* *} \mathrm{p}<0.01$ (two-tailed tests). 


\subsection{Analysis and Results}

MPLUS was used to perform SEM. To understand if it was a full mediation or partial mediation, a partial mediation model with the direct path between the perceived ease of use of AIS functions and AIS course acceptance is run (Figure 2). It was found that the direct effects of the perceived ease of use of AIS functions on AIS course acceptance were not statistically significant $(\beta=-0.00$, n.s.). In addition, the chi-square values were not significantly different between the full mediation and partial mediation models which meant adding the direct link between the perceived ease of use of AIS functions and AIS course acceptance did not improve the model fit significantly. As a result, the full mediation model, which is more parsimonious, is supported.

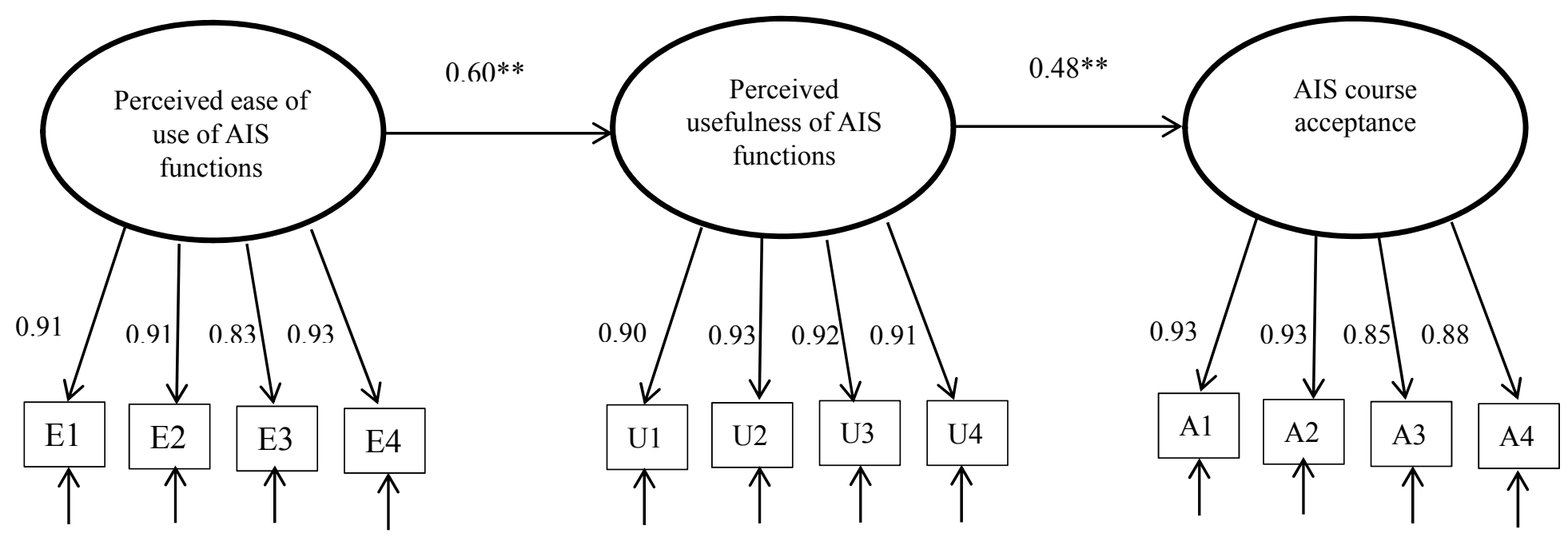

Figure 1. The full mediation model (the final model)

Note. $n=315$. The path coefficients are standardized. The control variables are not shown for ease of presentation.

$* * p<0.01$ (two-tailed tests).

The global fit indexes of the full mediation model (Figure 1) indicated that the data were consistent with the structural model $(\chi 2=393.48, \mathrm{df}=195 ; \mathrm{CFI}=0.95 ; \mathrm{RMSEA}=0.06 ;$ SRMR $=0.05)$. The result supported Hypothesis 1: perceived ease of use of AIS functions has a positive direct effect on the perceived usefulness of AIS functions $(\beta=0.60, p<0.01)$. The result supported Hypothesis 2: perceived usefulness of AIS functions has a positive direct effect on AIS course acceptance $(\beta=0.48, p<0.01)$. Lastly, Hypothesis 3 was also supported: the influence of perceived ease of use of AIS functions on AIS course acceptance is mediated by the perceived usefulness of AIS functions. The analysis showed that the standardized indirect effect was $0.29(p<0.01)$, supporting the perceived usefulness of AIS functions fully mediated the relationship between the perceived ease of use of AIS functions and AIS course acceptance. In the full mediation model, $\mathrm{R}^{2}$ between perceived use of use of AIS functions and perceived usefulness of AIS functions was 0.354 , while $\mathrm{R}^{2}$ between perceived usefulness of AIS functions and AIS course acceptance was 0.21 . 


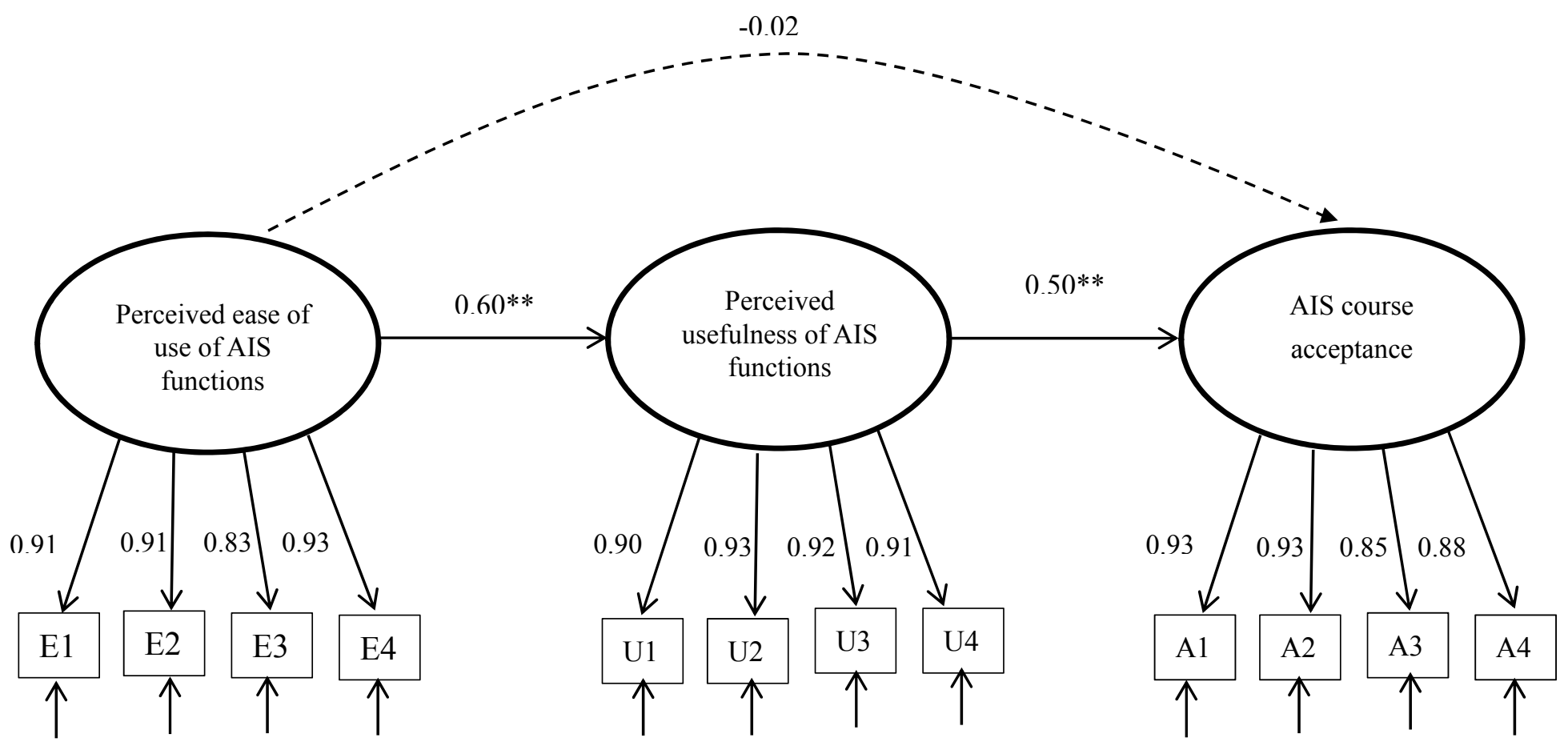

Figure 2. The partial mediation model

Note. $n=315$. The path coefficients are standardized. The control variables are not shown for ease of presentation.

$* * p<0.01$ (two-tailed tests).

\section{Discussion \& Recommendations}

This result shows that perceived ease of use of AIS functions has a strong positive direct effect on perceived usefulness of AIS functions $(\beta=0.60, p<0.01)$, and perceived ease of use of AIS functions explains $35.4 \%$ of perceived usefulness of AIS functions. The result is consistent with that of Van der Heijden (2004) and Igbaria et al. (1996). Students perceive that if the AIS functions are easy to use and they can become skillful easily at using the functions, then they also perceive the functions are useful in their work, such as, enhancing their effectiveness and productivity, and improve work performance. Educators may consider adopting user friendly AIS in their teaching and AIS developers may consider developing user friendly AIS for students because the perceived ease of use has a strong positive direct effect on perceived usefulness of AIS functions.

The study also shows that the perceived usefulness of AIS functions has a moderate direct effect on AIS course acceptance $(\beta=0.48, p<0.01)$, and perceived usefulness of AIS functions explains $21 \%$ of AIS course acceptance. The result is consistent with that of Davis (1989). Students perceive using AIS functions can enhance their effectiveness and productivity in work and can be useful and improve their work, they will then accept the AIS course more, such as, say positive things about the course, encourage others to take the course and take the course themselves. As AIS course is a core compulsory course in most accountancy or business programmes, if students perceive using AIS functions is useful, it may make them take and accept the AIS course easier which may lead to a more effective teaching and learning process. Educators may consider teaching those functions which are perceived useful to enhance students' interest in learning AIS.

The result also supports that the perceived usefulness of AIS functions mediates the relationship between the perceived ease of use of AIS functions and AIS course acceptance $(\beta=0.29, p<0.01)$ which is consistent with that of Davis (1985). The easier a system is to interact with, the less effort and resources needed to operate it, and one can have more time and resources to handle other activities (Radner \& Rothschild, 1975) leading to better job performance, eventually resulting a higher acceptance to the system. 


\section{Conclusion \& Future Research}

This study suggests that perceived ease of use of AIS functions has a strong positive effect on perceived usefulness of AIS functions and the perceived usefulness of AIS functions has a moderate positive effect on AIS course acceptance, and the perceived usefulness of AIS functions mediates the link between perceived ease of use of AIS functions and AIS course acceptance. Educators can consider choosing a user friendly AIS in teaching which can enhance the learning process of students and raise their interests and acceptance to AIS course eventually. AIS developers can also develop AIS with effective and efficient functions which help both teachers and students in their teaching and learning.

This research provides useful insights to both AIS educators and manufacturers, however, this study is an investigation on perceptions generally at one point of time and does not make reference to a specific accounting system or software and does not measure the change in perceptions before and after using a system or software. Besides, perceived ease of use of AIS functions explains 35.4\% of perceived usefulness of AIS functions and perceived usefulness of AIS functions explains $21 \%$ of AIS course acceptance, it indicates that there should be other variables relate to perceived usefulness of AIS functions and AIS course acceptance which have not been investigated in this study.

In future, studies can carry out a longitudinal study to investigate the change of perceptions over time and can carry out by using a specific system or software. Future research can add other variables in the model, such as motivation, enjoyment and satisfaction; and can break down the user acceptance into behavioral intention and word of mouth.

\section{Acknowledgement}

The authors would like to thank Mr Kent Hui for his comments and suggestions.

\section{References}

Anderson, J.C., \& Gerbing, D.W. (1988). Structural equation modeling in practice: A review and recommended two-step approach. Psychological Bulletin, 103(3), 411. https://doi.org/10.1037/0033-2909.103.3.411

Bagozzi, R.P., Yi, Y., \& Phillips, L.W. (1991). Assessing construct validity in organizational research. Administrative Science Quarterly, 421-458. https://doi.org/10.2307/2393203

Bressler, L.A., Manrique, J.R., \& Bressler, M.S. (2006). An econometric analysis of demographic, computer knowledge and experience factors affecting online education success: The case of online AIS/EDP auditing. AIS Educator Journal, 1(1), 57-66.

Charron, K., \& Raschke, R. (2014). Student perceptions and experiences using Jing and Skype in an Accounting Information Systems Class. Journal of Education for Business, 89(1), 1-6. https://doi.org/10.1080/08832323.2012.733740

Davis, F.D. (1989). Perceived Usefulness, Perceived Ease of Use, and User Acceptance of Information Technology. MIS Quarterly, 13(3), 319-340. https://doi.org/10.2307/249008

Davis, J.A. (1985). The Logic of Causal Order. Sage, Beverly Hills, CA, 1985. https://doi.org/10.4135/9781412986212

Edmunds, R., Thorpe, M., \& Conole, G. (2012). Student attitudes towards and use of ICT in course study, work and social activity: A technology acceptance model approach. British Journal of Educational Technology, 43(1), 71-84. https://doi.org/10.1111/j.1467-8535.2010.01142.x

Gefen, D., \& Straub, D.W. (1997). Gender differences in the perception and use of e-mail: An extension to the technology acceptance model. MIS Quarterly, 389-400. https://doi.org/10.2307/249720

Gerbing, D.W., \& Anderson, J.C. (1988). An updated paradigm for scale development incorporating unidimensionality and its assessment. Journal of marketing research, 186-192. https://doi.org/10.2307/3172650

Germain, R., Dröge, C., \& Daugherty, P.J. (1994). The effect of just-in-time selling on organizational structure: an empirical investigation. Journal of Marketing Research, 471-483. https://doi.org/10.2307/3151877

Groomer, S.M., \& Murthy, U.S. (1996). An empirical analysis of the accounting information systems course. Journal of Information Systems, 10(2), 103-127.

Gujarathi, M. (2005). Use of ERP software in accounting: A teaching note. Advances in Accounting Education, 7 , 207-220. 
Hackbarth, G., Dow, K., \& Janvrin, D.J. (2010). The influence of training environment on trainee expertise. AIS Educator Journal, 5(1), 95-112.

Hurt, R.L. (2013). Accounting information systems: Basic concepts and current issues (2nd ed.). New York: McGraw-Hill.

Igbaria, M., Parasuraman, S., \& Baroudi, J.J. (1996). A motivational model of microcomputer usage. Journal of Management Information Systems, 13(1), 127. https://doi.org/10.1080/07421222.1996.11518115

Kearns, G.S. (2014). The Importance of Accounting Information Systems in the Accounting Curricula: A CPA Perspective. AIS Educator Journal, 9(1), 24-40.

Kline, R.B. (1998). Principles and practices of structural equation modeling. New York: Guilford Press.

Mahoney, L.S., \& Welch, J.K. (2002). Teaching accounting information systems using personal computer movies. Advances in Accounting Education, 4, 119-138. https://doi.org/10.1108/s1085-4622(2002)0000004010

Normand, C. (2011). Dexter buys a surfboard: An exploratory study of the impact of a classroom activity and reflection on student perceptions of the first AIS course. AIS Educator Journal, 6(1), 11-31.

Pavlou, P.A. (2003). Consumer acceptance of electronic commerce: Integrating trust and risk with the technology acceptance model. International Journal of Electronic Commerce, 7(3), 101-134.

Radner, R. \& Rothschild, M. (1975). On the allocation of effort. Journal of Economic Theory, 10, 358-376. https://doi.org/10.1016/0022-0531(75)90006-X

Rose, J.M., Rose, A.M., \& Norman, C.S. (2005). A service-learning course in accounting information systems. Journal of Information Systems, 19(2), 145-172. https://doi.org/10.2308/jis.2005.19.2.145

Smith, L.M., \& Bain, C.E. (1993). The scope of the accounting information systems course: Based on textbook coverage and a faculty survey. The Accounting Educators' Journal, 5(2), 1-11.

Sun, H., \& Zhang, P. (2006). Causal relationships between perceived enjoyment and perceived ease of use: An alternative approach. Journal of the Association for Information Systems, 7(9), 618-645.

Van der Heijden, H. (2004). User acceptance of hedonic information systems. MIS Quarterly, 28(4), 695-704.

Van Meer, G., \& Adams, M. (1996). Accounting information systems curriculum: An empirical analysis of the views of New Zealand-based accounting academics and practitioners. Accounting Education: An International Journal, 5(4), 283-295. https://doi.org/10.1080/09639289600000029

Weli. (2015). Accounting Students Attitude towards Computer, the Acceptance of the Accounting Information System's Course and Teaching Method. Procedia - Social and Behavioral Sciences, 172, 18-25. https://doi.org/10.1016/j.sbspro.2015.01.330

Wu, F.H. (1983). Teaching accounting information systems: A synthesis. Issues in Accounting Education, 1(1), 132-145. 